\title{
Climatic Changes and Vulnerability of Household Food Utilization in Malaysian East Coast Economic Region
}

Md. Mahmudul Alam*

Senior Lecturer

School of Economics, Finance \& Banking

College of Business, Universiti Utara Malaysia

Kedah, Malaysia

E-mail: rony000@gmail.com

Tel: +601-6279 9091

Chamhuri Siwar

Emeritus Professor

Institute for Environment and Development (LESTARI)

National University of Malaysia (UKM)

43600 UKM Bangi, Selangor Darul Ehsan, Malaysia

E-mail: csiwar@ukm.edu.my

Basri Abdul Talib

Associate Professor

Faculty of Economics and Management

National University of Malaysia (UKM)

43600 UKM Bangi, Selangor Darul Ehsan, Malaysia

E-mail: basri@ukm.my

\author{
Abu N.M. Wahid \\ Managing Editor, the Journal of Developing Areas \\ Professor, Department of Economics and Finance \\ Tennessee State University \\ Nashville, Tennessee, USA \\ E-mail: awahid@tnstate.edu \\ Tel: +615-963-7149
}

*Corresponding author

\section{Citation Reference:}

Alam, M.M., Siwar, C., Talib, B., \& Wahid, A.N.M. (2018). Climatic Changes and Vulnerability of Household Food Utilization in Malaysian East Coast Economic Region. International Journal of Environment and Sustainable Development, 17(4), 331-346. (online) https://www.inderscienceonline.com/doi/abs/10.1504/IJESD.2018.096860

This is a pre-publication copy.

The published article is copyrighted by the publisher of the journal. 
Biographical notes: Md. Mahmudul Alam is a Senior Lecturer of Finance at Universiti Utara Malaysia (UUM). He is also affiliated with Accounting Research Institutes (ARI) at University Technology MARA (UiTM) in Malaysia and International Islamic University Chittagong (IIUC) in Bangladesh as a Research Associate. He obtained Ph.D. and Master's degrees in Environment and Development (Fin. \& Econ.) from National University of Malaysia (UKM) and Bachelor (Hons) degree in Business Administration (Fin. \& Econ.) from North South University (NSU) in Bangladesh. He has a good number of publications including 100+ articles in refereed journals and five books/ monographs. He has presented $60+$ articles in international conferences. He is recognized as one of the "Top Bangladesh Development Researchers of the Millennium" by BDRC. His research areas include sustainable development, ecological economics, Islamic economics, governance, finance \& investment, etc.

Chamhuri Siwar is an Emeritus Professor and Principal Research Fellow at the Institute for Environment and Development (LESTARI), National University of Malaysia (UKM). He has been serving UKM as a lecturer, head of department, and research fellow for more than 40 years. He graduated from UKM, Leeds and Iowa State University in the areas of Applied Economics, Agriculture and Resource Economics. He has successfully supervised 40 Ph.D. and 20 Master's students. He has been external examiners of numerous graduate students in Malaysia and abroad. He has wide publications in reputed international and national journals. His area of specialization includes Agricultural and Resource Economics, Rural Economics, Environmental Economics, Poverty and Income Distribution, Sustainable Economics, Socioeconomics Impact, and Sustainable Livelihood Studies.

Basri Abdul Talib is an Associate Professor at the Faculty of Economics and Management at the National University of Malaysia (UKM). He obtained PhD in Agricultural Economics from the University of Aberdeen in 1998. His research interests are related to the environmental economics which includes studies on the effects of climate change and adaptation strategies. His research also focuses on the agricultural economics and rural development, particularly in the study of productivity and efficiency in commodities and poverty alleviation programs. He has supervised a number of postgraduate students and has published several articles in refereed journals.

Abu N. M. Wahid is a Professor of Economics at Tennessee State University and the Managing Editor of the Journal of Developing Areas. Up until now, he has produced SIX books as author, editor, and co-editor and has made about 60 publications in the form of refereed journal articles and book chapters. Professor Wahid received many research grants including the Fulbright Research Fellowship in 1997. He is the recipient of the faculty excellence awards for research at Tennessee State University and Eastern Illinois University. Professor Wahid has visited academic institutions in about 20 different countries to give public lectures and seminar presentations. Since 2008, he delivered 4 Keynote addresses in international conferences held in Malaysia, the Philippines, and Taiwan. He read and reviewed $20 \mathrm{Ph}$.D. dissertations as external examiner for various reputed universities around the world. 


\title{
Climatic Changes and Vulnerability of Household Food Utilization in Malaysian East Coast Economic Region
}

\begin{abstract}
Sustainable food security at household level is one of the emerging issues for all nations. There are several factors such as social, economic, political, demographic, natural, and livelihood strategies that causes to the vulnerability of the status of household food security. Therefore examining the vulnerability of these factors is essential to identify the reason and recognize the most vulnerable communities. This study is an attempt to study on the vulnerability of the factors of household food utilization and its linkage with climatic changes in Malaysia. The study is based on primary data collected in the months of July - October, 2012 through a questionnaire survey on 460 low income households from East Coast Economic Region (ECER) in Malaysia. The samples were selected from E-Kasih poor household database, based on cluster random sampling technique. The study found that the vulnerability of the factors of household food utilization has increased statistically significantly over the last five years period due to difference between rural and city food quality, occurrences of natural disasters, incidences of mosquitoes, insects, pest, etc., and diseases like dengue, malaria, heat stretch, cold, skin disease, etc. This study suggests that the food security programs need to be integrated with climatic change adaptation programs to ensure more effective and sustainable household food security in future, especially among the poor and low income group.
\end{abstract}

Key words: Climatic Changes; Household Food Security; Food Utilization; Vulnerability; Poverty

Jel Code: I32, Q54, P48

\section{Introduction}

Food security is a critical global aspect of the individual and household wellbeing regardless of whether it is viewed locally, globally or within communities. Hunger and food insecurity are detrimental to the basic rights of a human being and are a prelude to problems including health, nutrition, and development. The household food security is a more current understanding of the food security concept. Most of the literature in this subject from the 1980s assumed national food security to be similar to food self-sufficiency and this poses a few challenges. According to Debebe (1995) household food security represents factors, which are linked to the actions of "...acquisition, household procurement strategies and socio-economic condition of the society."

Various types of indicators are required to measure the many different aspects of food security at an individual, household, and country levels (Hoddinott, 1999). Various correlated environmental, socioeconomic, and political aspects that need multi-pronged approaches have an influence on food security (Debebe, 1995). Negatu (2006) suggested that one of the factors that has an effect on food security is land tenure insecurity and the other is not having accessibility to productive resources, low educational level, reduction in land holdings, not having accessibility to proper transport structure, low livestock productivity, unaware of suitable interventions, bad storage technology, and a high unemployment level. Other factors that also have an effect on food security include crop pests, drought, and sudden torrential rainfall, not having a draught oxen, increased population and shortage of land (Negatu, 2006). 
Natural indicators result in specific higher variation in production costs and production that are linked to irrigation, infection and insecticide treatment and higher losses (Lovendal \& Knowles, 2006). Depending on the capability of traders bringing in food from various other areas and the available stock levels, this could potentially disrupt food supply and cause prices to increase further. The main environmental indicators prove to be trends and not shocks that occur. They negatively affect production through reduced soil fertility and lower yields as well as the rise of production cost per unit. The profitability of farming and the potential to gain income from other activities that are resource based are limited.

There are four dimensions of food security such as availability of food, stability of its supply, accessibility to food, and utilization of food. A vulnerable food system occurs when any dimensions of food security are insecure and uncertain. Understanding the vulnerability of the factors of food security can assist in the identification and comprehension of the fundamental dimension of a population's wellbeing and to recognize the most vulnerable communities in the regions or subgroups.

As like as other dimensions, household food utilization is also very important for household food security that indicates the significance of non-food inputs in food security such as proper diet, clean water, healthcare, and sanitation to gain nutritional well-being where all physiological requirements are met. From the health aspect, WHO reported that hygiene, sanitation, and unsafe water supply, are the third most significant indicators that caused poor health and even death in 2000 (Makinen et al., 2000). In the countries that are developing, the brunt of these indicators is taken on by children, giving rise to immediate food insecurity issues. In addition, these health-based indicators also cause vulnerability to increase by lowering the educational achievement of those affects given the high absenteeism and reduced cognitive ability caused by poor nutrition. Health indicators show periodical or permanent loss of labor time which signals reduced income and lowered food accessibility, lowered capability to take in micro- and macro nutrients, and in some instances where a whole community is affected, locally lowered food production. Social indicators refer to not having sufficient access to normal resources and sufficient networking power during difficult times causing reduced income and being unable to draw from resources in the community.

According to Lovendal \& Knowles (2006), food utilization and food accessibility are mainly affected at the household by economic, social, health, and lifecycle related indicators. Households that are dependent on subsistence farming and no other income generating activities or having accessibility to markets, these crises can lower the availability of food. Life events like weddings and funerals often incur a large amount of additional expense thus also lowering the capability for purchase of food. Likewise, disability, injuries, and illnesses incur extra expenses and also lower the supply of labor and income, thus causing insufficient utilization of food. The economic indicators are able to lower food accessibility via the loss of income by being unemployed or due to the failure of income-generating activities such as farming, small manufacturing or trade.

Malaysia is a very fast growing developing country. So, there are scopes of frequent changes in the economic variables that would affect food security. Moreover, the climatic factors are changing very rapidly in Malaysia and have been having adverse impacts on food production (Alam et al., 2010a; 2010b). Even, that household food insecurity is not only related to social and economic factors, but also statistically significantly linked to the direct and indirect impacts of climatic factors (Alam et al., 2011). Previous studies showed that $50 \%$ or more of the low-income rural households face some level of food insecurity with 
$34.5 \%$ child hunger (Shariff \& Khor, 2008). The percentage of households with food insecurity in Malaysia is higher in urban low-income households, such as $66.6 \%$ (Zalilah, 1998) and $65.7 \%$ (Zalilah \& Ang, 2001) compared to rural low-income households 58\% (Shariff \& Khor, 2008). Another recent study showed that among the poor and low income household, $23.3 \%$ are mildly food insecure, $14.3 \%$ are moderately food insecure, and $9.6 \%$ are severely food insecure in Malaysia (Alam et al., 2016a).

Therefore, to understand the level of vulnerability of household food security, this study is an attempt to check food utilization - one of the important dimensions of household food security, and its linkage with climatic changes in Malaysia.

\section{Climate Change and Household Food Utilization}

Climate changes affect the fundamental aspects of food production, which include water, soil, and biodiversity, negatively. In a broader viewpoint, it has an effect on all the four types of food security's dimensions (FAO 2008). FAO also highlighted the impacts of the components of climatic changes on household food utilization that are given in Table 1.

Table 1: Impact of the Components of Climatic Change on Household Food Utilization

\begin{tabular}{|c|c|}
\hline Components of Climate Change & Food Utilization \\
\hline Increase in global mean temperatures & $\begin{array}{l}\text { - Risk of dehydration } \\
\text { - Risk of ill health from eating food that is spoiled } \\
\text { - Ability of body to process food reduced due to heat } \\
\text { stress or diseases }\end{array}$ \\
\hline $\begin{array}{l}\text { Gradual changes in precipitation (increase in the } \\
\text { frequency, duration and intensity of dry spells and } \\
\text { droughts) }\end{array}$ & $\begin{array}{l}\text { - Risk of dehydration } \\
\text { - Ability of body to process food reduced due to } \\
\text { diseases } \\
\text { - Dietary adjustments with different nutritional content }\end{array}$ \\
\hline $\begin{array}{l}\text { Gradual changes in precipitation (increase in the } \\
\text { frequency, duration and intensity of dry spells and } \\
\text { droughts) }\end{array}$ & $\begin{array}{l}\text { - Risk of dehydration } \\
\text { - Ability of body to process food reduced due to } \\
\text { diseases } \\
\text { - Dietary adjustments with different nutritional content }\end{array}$ \\
\hline $\begin{array}{l}\text { Impacts of increase in the frequency and intensity } \\
\text { of extreme weather events (increase in annual } \\
\text { occurrence of high winds, heavy rains, storm } \\
\text { surges, flash floods and rising water levels } \\
\text { associated with tornados, tropical storms, and } \\
\text { prolonged heavy rains) }\end{array}$ & $\begin{array}{l}\text { - Food safety is compromised by water pollution and } \\
\text { damage to stored food } \\
\text { - Ability of body to process food reduced due to } \\
\text { diseases }\end{array}$ \\
\hline
\end{tabular}

Source: Compilation from Table 1 (A, B, C.1, C.2, D, E) of FAO (2008) study

The effects of climate change on food utilization are a major consideration especially for developing nations. In general, these changes will have a detrimental effect on the achievement of human rights, especially on rights to clean water and directly linked to the right to have food. It is projected that by $2080,1.1$ to 3.2 billion of the world's population will face water scarcity (according to the Special Report on Emissions Scenarios of socioeconomic development); 200 to 600 million will face hunger; and 2 to 7 million others will face coastal flooding annually (Yohe et al., 2007). 
This affect may happen in many ways such as higher frequency of critical climatic occurrences; rising sea-level and flooding in coastal areas, resulting in contamination and/or salination of agricultural land and water; effects of water scarcity and temperature increase on physiology of animals or plants; advantageous effects on crop production due to $\mathrm{CO}_{2}$ "fertilization;" effects on pest species, plant and livestock diseases such as zoonosis, resulting in loss of animals and crops; destruction of fisheries, aquaculture, livestock, and forestry; and disrupted sustainability: socioeconomic and political/armed conflicts and demographical effects.

Climate changes may have an effect on health and food usage as a consequence of malnutrition. As an example, people from in water-scarce areas would experience reduced water availability, specifically in the sub-tropics, with shortage of safe drinking water and food. Increased precipitation and flooding will possibly cause increased cases of diarrhea and infectious diseases. There may be increased risk of emerging zoonosis given the changes in the pathogens' survival in the surrounding areas, changes in migratory patterns, vectors and carriers and natural ecosystems. The increase of the livestock population in new regions with threats of concomitant diseases must be considered.

Most of the diseases related to climate are expected to rise from the increase in malnutrition and diarrheal diseases which mainly impacts food utilization and nutrient absorption. Worldwide reports suggest the link between diarrheal and monthly temperature episodes and between monthly reports of water-borne disease outbreaks and extreme cases of rainfall. In Peru, higher temperatures have been linked to increased cases of diarrheal disease among children and adults, where diarrheal reports have increased by $8 \%$ for each degree of increase in temperature (Checkley et al., 2000). Diarrheal diseases that are food-borne such as Salmonellosis have increased by $12 \%$ for each degree of increase in monthly or weekly temperature of more than the $6^{\circ} \mathrm{C}$ ambient temperature (Kovats et al., 2004). Rising ocean temperatures are resulting in higher densities of Vibrio spp. (diarrheal agent) in shellfish (Zimmerman et al., 2007). Climate change is expected to cause the burden of diarrheal diseases to increase in low-income areas in 2020 by about $2-5 \%$ and will affect populations with low-income who are already facing a large burden of diseases (McMichael, 2004; Campbell-Lendrum et al., 2003). Countries that have a GDP of US\$6,000 per annum or more are said to have no extra diarrhea risk.

Malaria especially is anticipated to transform its spread due to climate change (IPCC, 2007). In the coastal regions, additional people may face diseases that are vector and waterborne due to flooding caused by the rise in sea-levels. Health risks can also be linked to changes in diseases from either increased or decreased precipitation, lowering of people's capacity to utilize food effectively and often resulting in the need for improved nutritional intake.

Food safety may be affected in many ways given the effects of climate change. Rising temperatures will cause food to spoil faster, unless care is given to refrigeration and cooling issues and processing food faster to expand their lifespan. The lack of water will affect the processing and preparing of food especially in the subtropical regions where people may have to change to dry processing or find new cooking ways. The changes in rainfall and rising temperatures will change the way land is used and this will cause people to spend their time differently. Children may have to do food preparation as parents will have to work and this might increase the risk of bad hygienic practices to be used. 
Climate variability and changes can cause contamination of food with non-infectious hazards like biotoxins (marine or mycotoxins toxins) and chemicals, which may affect animal feed and food stability, utilization and/or access. Food contamination from chemicals may lead to suggestions to limit consuming food that is locally produced to protect human health, hence lowering the dietary choice of rural and indigenous people and compromising their conventional diet. Moreover, rising ocean temperatures are resulting in higher levels of methy mercury in marine mammals and fish, resulting in recommendations to control the consumption of marine and fish fats by indigenous people and pregnant women in the polar areas (Booth \& Zeller, 2005; Kuhnlein et al., 2003).

Physiological usage of consumed foods also impacts nutritional status, and this is influenced by illnesses. Climate change will create new trends of diseases and pests to emerge, which will affect humans, animals, and plants, and pose new food security risks, human health, and food safety. Rising cases of water based diseases in flood-prone regions, vector changes for climate related diseases and pests, and emergence of various new diseases could impact the food chain and people's physiological ability to get the required nutrients from the consumed foods. Changes in vector are almost a certainty for diseases and pests that flourish only at specific temperatures and under specific humidity and irrigation management regimes. These will expose crops, fish livestock, and humans to new risks. They will also add new stress on homemakers in the household who are usually women, and health care institutions will need to find new ways to cope.

\section{Data and Methodology}

\subsection{Data Collection}

Data for this study were collected through an extensive questionnaire survey at household level in East Coast Economic Region (ECER) in Malaysia. ECER is more than half of the Peninsular Malaysia with the area of about $66,000 \mathrm{sq} \mathrm{km}$ that covers the states Kelantan, Terengganu, Pahang, and Mersing in Johor. ECER is very crucial for two major reasons; (a) ECER is the most vulnerable area in Malaysia due to climatic changes and (b) the income level of this region is low and poverty rate is high that is an obstacle to achieve Vision 2020 (Alam et al. 2016b).

This study is based on primary data collected from 460 households in the urban and rural areas of ECER. The urban area of Kuantan and rural area of Pekan were selected from Pahang state. The urban area of Kota Bharu and rural area of Tumpat were chosen from Kelantan state. The urban area of Kuala Terengganu and rural area of Maring were taken from Terengganu state. A questionnaire guide technique was used to collect data. The survey was conducted by the regular enumerators of the Implementation Coordination Unit (ICU) from Pahang, Kelantan, and Terengganu states in the months of July - October, 2012. The survey followed the cluster random sampling technique. Initially the samples were clustered by location and then by poverty category. Finally, from each category, samples were picked up randomly from the E-Kasih database. E-Kasih system has been an integrated database system that has enlisted poor households at the national level to plan, implement, and monitor poverty programs in Malaysia.

\subsection{Variables and Statistical Analysis}


There are many factors relevant to the vulnerability of household food security due to climatic changes and non-climatic/general changes. To measure the degree of vulnerability of these factors, the perception of the households has been shown in two forms - using the scale of 1 (very low) to 5 (very high), and determine the changes by comparing current status with the scenario of 5 years ago. This study also checks the equality of two means between the current status of the relevant factors and five years earlier factors through ANOVA $\mathrm{F}$ statistics for Chi-Square $\left(\chi^{2}\right)$ Two Sample Test.

$$
\chi^{2}=\sum_{i=1}^{n} \frac{\left(O_{i}-E_{i}\right)^{2}}{E_{i}}
$$

Here, $\mathrm{O}_{\mathrm{i}}=$ Current Status of $i$ - th Factors (Ordinal Data)

$\mathrm{E}_{\mathrm{i}}=$ Previous Status of $i$ - th Factors (Ordinal Data)

The variables that are considered in this study are as follows:

X1 Difference between rural and city food quality in Malaysia

X2 Food quality as nutrition level in local market in Malaysia

X3 Food quality as food safety in local market in Malaysia

X4 Quality of drinking water in Malaysia

X5 Occurrences of natural disasters at local level

X6 Incidences of mosquitoes, insects, pest, etc.

X7 Incidences of disease like dengue, malaria, heat stretch, cold, skin disease, etc.

\section{Analysis and Discussions}

\subsection{Demographic Characteristics}

Among the respondents of the study, around $60 \%$ are selected from the urban area and $40 \%$ from the rural area. In total, $69.8 \%$ are male and $30.2 \%$ are female respondents. The male respondents are $69.7 \%$ among the urban respondents and $69.8 \%$ among the rural respondents. Male are the majority group, but the respondents represent the household data.

The average age of all respondents is 50.7 years whereby male is 48.9 and female is 54.7 years old. Among the male respondents, the maximum age is 83 and minimum age is 26 years old. Among the female respondents, the maximum age is 83 and minimum age is 25 years old. In total, only $3.7 \%$ are below 30 years old, and $23 \%$ are above 60 years old. The maximum number of respondents is in the age range of 30-40 years at $35.2 \%$ of the total. Exception is only for the rural area of Kelantan where maximum number of participants is in the age group of 50-60 years old.

Most of the respondents have secondary education (46.5\%) followed by basic primary education $(35.9 \%)$. Only $3 \%$ of the respondents have certificate/diploma level education and $14.6 \%$ are illiterate. Numbers of illiterate people are higher in the urban area at $17.3 \%$ whereas in the rural area, it is at $12.7 \%$.

Among the total respondents, $72.8 \%$ are married whereas $3 \%$ are unmarried. Total of $24.2 \%$ of the respondents are found to be widowed or divorced. Most of the families $(20.7 \%)$ have 5 persons in the household and average family members are 5.6 persons per household. 
There are 1-3 persons available in $17.9 \%$ of the households. There are 8 or more people available in $17.9 \%$ of the households.

Among the respondents, most of the households (63.3\%) have no children (below 6 years) and average number of children (below 6 years) per household is 0.6 . Majority of them have only one child and their ratio is $20.9 \%$. Most of the households $(24.1 \%)$ have no school going children (below 6 years) and average number of school going children per household is 2.2. Families that have $2-3$ school going children are $40.3 \%$.

Among the households, $83.7 \%$ have their own residence. This proportion is same for both urban and rural households. In the rural area, 50.9\% of houses are made of mixed type (used both brick and wood) of house. In the urban area, $34.6 \%$ of people live both in mixed and wood made houses.

The respondents are engaged in various types of jobs, such as babysitter, batik designer, building contractor, small business, bus driver, canteen assistant, car service, carpenter, chief, clerk, cleaner, construction worker, craftsman, electrical technician, van driver, fisherman, fruit dealer, furniture shop, gardener, jewelry shop, hawker, daily labor, farmer, meson, painter, plumber, saloon worker, security guard, imam, teacher, government job, tailor, taxi driver, welding, factory labor, etc. In $90 \%$ of the cases, the heads of the households do not have any supplementary job. The rural households have more supplementary job options than urban households. The spouses of most of the households $(88.3 \%)$ are not engaged in a job. However, the number of spouses of urban household engaged in a job is more than the number of spouses of rural households engaged in a job.

Around $76.3 \%$ of the households have only one earning member; $15.7 \%$ have two earning members, and $5.4 \%$ have three earning members. The proportion is almost the same for the urban and rural areas. At the household level, on an average, the earning family members to total family members ratio is 0.287 , indicating that on an average only $28.7 \%$ of the family members are engaged in economic activities. Among the surveyed households, in $47.2 \%$ of the cases, this ratio is up to 0.2 , and in $3.7 \%$ of the cases, the ratio is 1 which means a single person family.

The household income of most of the respondents is between RM 501-1000 range. $35 \%$ of the household's monthly income is up to RM500, which is more in urban area in comparison to the rural area. Only 3.6\% household's income is above RM 2000, which is more in the rural area in comparison to the urban area. The per-capita income of most of the respondents is between RM 100-200 range. The per-capita income of 59.3\% of respondents is up to RM200. The higher income ranges for urban people are more than the rural people, indicating the income of the rural area is less than the urban area.

According to the survey findings, around 55\% are still poor and hard core poor. Around 9\% of the people have an income of more than RM 400, who might be excluded in the low income group list soon. The people in the low household income group also belong to the low per-capita income group. ${ }^{1}$

\footnotetext{
${ }^{1}$ The hardcore poor are considered those with Ringgit Malaysia (RM) 0-110 income per person per month, for the rural area and RM 0-120 RM per person per month, for the urban area. The poor are considered those with RM 111-185 income per person per month, for the rural area and RM 121-200 per person per month, for the
} 
The distribution of income among the surveyed household is not so wide. However, here, the top $10 \%$ receive $23.2 \%$ of the total income while the bottom $10 \%$ receive only $3.4 \%$ of the income, and the top $20 \%$ receive $36.9 \%$ of the total income while the bottom $20 \%$ receive only $8.8 \%$.

The degree of inequality is measured by Inequality Ratio, also known as Kuznets ratio. The ratio measures inequality through the ratio of income of top $20 \%$ to income of bottom $40 \%$. Here, the ratio is $1.624((1-0.631) / 0.227)$, meaning that the degree of inequality at household level is more than one and a half times. Moreover, if the inequality ratio is measured in terms of population instead of household, the degree of inequality is roughly $1.405(0.358 / 0.255)$. The degree of inequality at the population level is less than the household level because there are likely less population in the poorer households and more population in the richer households.

The most vulnerable groups are those who have no household saving and as a result per capita savings is nil. Among the respondents, around $82 \%$ do not have any savings. Therefore, any type of spike in regular life due to natural disasters, disease, crime, or social issues will push them towards borrowing. The rural households are less savings holders compared to urban households.

\subsection{Assessments of Vulnerability}

The changes in the difference between rural and city food quality (X1) over the last five years in Malaysia are found statistically significant at $1 \%$ level (Table 3). However, only $36 \%$ of the respondents mention the change is positive and overall the average score increases from 2.91 to 3.25 (Table 2). It indicates that the vulnerability of the difference between rural and city food quality in Malaysia has increased over the time.

Table 2: Changes in the factors of food utilization over the five years period

\begin{tabular}{|c|c|c|c|c|c|c|c|c|c|c|}
\hline \multirow[b]{2}{*}{ Issues } & \multirow{2}{*}{$\begin{array}{c}\text { Time } \\
\text { Frame }\end{array}$} & \multicolumn{5}{|c|}{ Observation Scale* } & \multirow{2}{*}{$\begin{array}{l}\text { Average } \\
\text { value of } \\
\text { the score }\end{array}$} & \multirow[b]{2}{*}{ S.D. } & \multirow{2}{*}{$\begin{array}{l}\text { Proportion of } \\
\text { High (4 \& 5) } \\
\text { Observation }\end{array}$} & \multirow{2}{*}{$\begin{array}{c}\text { Proportion of } \\
\text { Low (1 \& 2) } \\
\text { Observation }\end{array}$} \\
\hline & & 1 & 2 & 3 & 4 & 5 & & & & \\
\hline \multirow[t]{2}{*}{$\mathrm{X} 1$} & Current & 30 & 27 & 247 & 110 & 46 & 3.25 & 0.95 & $33.9 \%$ & $12.4 \%$ \\
\hline & 5 years ago & 33 & 89 & 241 & 80 & 17 & 2.91 & 0.89 & $21.1 \%$ & $26.5 \%$ \\
\hline \multirow[t]{2}{*}{$\mathrm{X} 2$} & Current & 29 & 66 & 161 & 179 & 25 & 3.23 & 0.98 & $44.3 \%$ & $20.7 \%$ \\
\hline & 5 years ago & 35 & 148 & 235 & 38 & 4 & 2.63 & 0.78 & $9.1 \%$ & $39.8 \%$ \\
\hline \multirow[t]{2}{*}{ X3 } & Current & 34 & 38 & 191 & 169 & 28 & 3.26 & 0.96 & $42.8 \%$ & $15.7 \%$ \\
\hline & 5 years ago & 28 & 143 & 209 & 67 & 13 & 2.77 & 0.87 & $17.4 \%$ & $37.2 \%$ \\
\hline \multirow[t]{2}{*}{$\mathrm{X} 4$} & Current & 37 & 26 & 164 & 167 & 66 & 3.43 & 1.06 & $50.7 \%$ & $13.7 \%$ \\
\hline & 5 years ago & 42 & 120 & 212 & 58 & 28 & 2.80 & 0.98 & $18.7 \%$ & $35.2 \%$ \\
\hline \multirow[t]{2}{*}{ X5 } & Current & 214 & 46 & 121 & 57 & 22 & 2.19 & 1.27 & $17.2 \%$ & $56.5 \%$ \\
\hline & 5 years ago & 196 & 84 & 133 & 42 & 5 & 2.08 & 1.08 & $10.2 \%$ & $60.9 \%$ \\
\hline \multirow[t]{2}{*}{ X6 } & Current & 129 & 86 & 138 & 70 & 37 & 2.57 & 1.26 & $23.3 \%$ & $46.7 \%$ \\
\hline & 5 years ago & 136 & 114 & 123 & 82 & 5 & 2.36 & 1.12 & $18.9 \%$ & $54.3 \%$ \\
\hline \multirow[t]{2}{*}{$\mathrm{X} 7$} & Current & 177 & 70 & 121 & 64 & 28 & 2.34 & 1.28 & $20.0 \%$ & $53.7 \%$ \\
\hline & 5 years ago & 183 & 79 & 114 & 78 & 6 & 2.23 & 1.17 & $18.3 \%$ & $57.0 \%$ \\
\hline
\end{tabular}

*Scale: 1= Very Low, 2= Low, 3= Normal, 4= High, 5= Very High

urban area. The recently and previously marginally non-poor (mudah miskin and terkeluar) are more than RM 185 , per person per month, for the rural area and RM 200, per person per month, for the urban area. 
Table 3: Statistical significance of the changes in the factors of food utilization over the five years period

\begin{tabular}{crrrc}
\hline \multirow{2}{*}{ Issues } & \multicolumn{3}{c}{ Perception of Changes } & \multirow{2}{*}{$\begin{array}{c}\text { Chi-Square } \\
\text { Value }\end{array}$} \\
\cline { 2 - 4 } & \multicolumn{1}{c}{ Decrease } & \multicolumn{1}{c}{ Same } & \multicolumn{1}{c}{ Increase } & $534.9^{*}$ \\
X1 & $59(12.8 \%)$ & $233(50.7 \%)$ & $168(36.5 \%)$ & $476^{*}$ \\
X2 & $42(9.1 \%)$ & $209(45.4 \%)$ & $209(45.4 \%)$ & $399.1^{*}$ \\
X3 & $57(12.4 \%)$ & $212(46.1 \%)$ & $191(41.5 \%)$ & $313.2^{*}$ \\
X4 & $56(12.2 \%)$ & $185(40.2 \%)$ & $219(47.6 \%)$ & $627.2^{*}$ \\
X5 & $43(9.3 \%)$ & $349(75.9 \%)$ & $68(14.8 \%)$ & $485.9^{*}$ \\
X6 & $83(18 \%)$ & $256(55.7 \%)$ & $121(26.3 \%)$ & $587.5^{*}$ \\
X7 & $74(16.1 \%)$ & $290(63 \%)$ & $96(20.9 \%)$ & \\
\hline
\end{tabular}

* Significant at $1 \%$ level

The changes in the food quality as nutrition level at local market (X2) over the last five years in Malaysia are found statistically significant at $1 \%$ level (Table 3). However, only $45 \%$ of the respondents mention the change is positive and overall the average score increases from 2.63 to 3.23 (Table 2). It indicates that the vulnerability of the food quality as nutrition level at local market in Malaysia has decreased over the time.

The changes in the food quality as food safety at local market (X3) over the last five years in Malaysia are found statistically significant at $1 \%$ level (Table 3). However, only $41.5 \%$ of the respondents mention the change is positive and overall the average score increases from 2.77 to 3.26 (Table 2). It indicates that the vulnerability of the status of food quality as food safety at local market in Malaysia has decreased over the time.

The changes in the quality of drinking water (X4) over the last five years in Malaysia are found statistically significant at $1 \%$ level (Table 3 ). However, only $47.6 \%$ of the respondents mention the change is positive and overall the average score increases from 2.8 to 3.43 (Table 2). It indicates that the vulnerability of the status of quality of drinking water in Malaysia has decreased over the time.

The changes in the occurrences of natural disasters at local level (X5) over the last five years are found statistically significant at $1 \%$ level (Table 3). However, only $14.8 \%$ of the respondents mention the change is positive and overall the average score increases from 2.08 to 2.19 (Table 2). It indicates that the vulnerability of the occurrences of natural disasters at local level has increased over the time.

The changes in the incidences of mosquitoes, insects, pest, etc. (X6) over the last five years are found statistically significant at $1 \%$ level (Table 3). However, only $26.3 \%$ of the respondents mention the change is positive and overall the average score increases from 2.36 to 2.57 (Table 2). It indicates that the vulnerability of the incidences of mosquitoes, insects, pest, etc. has increased over the time.

The changes in the incidences of disease like dengue, malaria, heat stretch, cold, skin disease, etc. (X7) over the last five years are found statistically significant at $1 \%$ level (Table 3 ). However, only $20.9 \%$ of the respondents mention the change is positive and overall the 
average score increases from 2.23 to 2.34 (Table 2). It indicates that the vulnerability of the incidences of disease like dengue, malaria, heat stretch, cold, skin disease, etc. has increased over the time.

Table 4: Climatic influences on the changes in factors of food utilization over the five years period

\begin{tabular}{|c|c|c|c|c|c|c|c|c|c|}
\hline \multirow{2}{*}{ Issues } & \multicolumn{5}{|c|}{ Observation Scale* } & \multirow{2}{*}{$\begin{array}{l}\text { Average } \\
\text { value of } \\
\text { the score }\end{array}$} & \multirow{2}{*}{ S.D. } & \multirow{2}{*}{$\begin{array}{l}\text { Proportion of } \\
\text { High (4 \& 5) } \\
\text { Observation }\end{array}$} & \multirow{2}{*}{$\begin{array}{l}\text { Proportion of } \\
\text { Low (1 \& 2) } \\
\text { Observation }\end{array}$} \\
\hline & 1 & 2 & 3 & 4 & 5 & & & & \\
\hline $\mathrm{X} 1$ & 355 & 29 & 67 & 8 & 1 & 1.42 & 0.82 & $2.0 \%$ & $83.5 \%$ \\
\hline $\mathrm{X} 2$ & 346 & 30 & 59 & 22 & 3 & 1.49 & 0.93 & $5.4 \%$ & $81.7 \%$ \\
\hline $\mathrm{X} 3$ & 337 & 44 & 65 & 12 & 2 & 1.47 & 0.86 & $3.0 \%$ & $82.8 \%$ \\
\hline $\mathrm{X} 4$ & 298 & 22 & 105 & 28 & 7 & 1.75 & 1.09 & $7.6 \%$ & $69.6 \%$ \\
\hline $\mathrm{X} 5$ & 284 & 53 & 75 & 22 & 26 & 1.81 & 1.20 & $10.4 \%$ & $73.3 \%$ \\
\hline $\mathrm{X} 6$ & 235 & 103 & 65 & 30 & 27 & 1.94 & 1.20 & $12.4 \%$ & $73.5 \%$ \\
\hline $\mathrm{X} 7$ & 297 & 56 & 65 & 17 & 25 & 1.73 & 1.16 & $9.1 \%$ & $76.7 \%$ \\
\hline
\end{tabular}

*Scale: 1= Very Low, 2= Low, 3= Normal, 4= High, 5= Very High

For all of the cases, most of the respondents mention that the influences of climatic factors are low for the changes of these factors of food utilization over the five years time (Table 4).

\section{Conclusions}

The study found that the vulnerability of the factors of food utilization has changed statistically significantly over the last five years period. The mean values of the current status of these factors of household food security differ significantly at $1 \%$ significance level from the scenario of 5 years ago. The vulnerability of food utilization increases due to difference between rural and city food quality, occurrences of natural disasters, incidences of mosquitoes, insects, pest, etc., and diseases like dengue, malaria, heat stretch, cold, skin disease, etc. However, vulnerability of food utilization decreases due to food quality as nutrition level at local market, the food quality as food safety at local market, and quality of drinking water. However, most of the cases climatic issues were found less responsible for the changes of these factors.

There should be some initiatives taken by government in response to these factors that increase the vulnerability of household food utilization. There should be a proper monitoring body to ensure safe and nutritious food available both in the urban and rural areas, especially at the time of natural calamity or off season. At the same time, special aid and incentive programs as well as awareness creations programs are also needed to adapt with natural disasters and climatic incidences like increases of mosquitoes, insects, pest, etc., and diseases like dengue, malaria, heat stretch, cold, skin disease, etc.

Though Malaysia is adversely affected by climatic change, the factors of food utilization has not affected yet remarkably. However, climate change is considered as one of the major potential threats for household food security in Malaysia. Therefore, to ensure sustainable household food security in Malaysia, design of food security programs must integrate climatic change into the picture, and food security approaches must recognize climate change as an important driver. This integration also increases household capacity to adapt to climatic change. At the same time, climate change adaptation approaches and strategies to reduce vulnerability to climate change also increases household food security. 


\section{Acknowledgement}

We are thankful to Ministry of Science, Technology and Environment of the Government of Malaysia for generously funding the research, under the Research University Grant Project UKM-GUP-PI-08-34-081 and FRGS/1/2012/SS07/UKM/01/3.

\section{References}

Alam, M.M., Siwar, C., \& Al-Amin, A.Q. 2010a. Climate Change Adaptation Policy Guidelines for Agricultural Sector in Malaysia, Asian Journal of Environmental and Disaster Management 2(4): 463-469.

Alam, M.M., Siwar, C., \& Mohd Ekhwan, T. 2010b. Socioeconomic Study of Climate Change: An Assessment of Agriculture and Livelihood Sustainability on Paddy Farming in Malaysia, LAP Lambert Academic Publishing: Saarbrucken, Germany.

Alam, M.M., Siwar, C., Talib, B., \& Mohd Ekhwan, T. 2011. The Relationships between the Socioeconomic Profile of Farmers and Paddy Productivity in North-West Selangor, Malaysia, Asia-Pacific Development Journal 18(1): 161-173.

Alam, M.M., Siwar, C., Wahid, A.N.M., \& Talib, B. 2016a. Food Security and Low-Income Households in the Malaysian East Coast Economic Region: An Empirical Analysis. Review of Urban \& Regional Development Studies, 28(1): 2-15.

Alam, M.M., Talib, B., Siwar, C., \& Wahid, A.N.M. 2016b. Climate Change and Food Security of the Malayan East Coast Poor: A Path Modeling Approach. Journal of Economic Studies, 43(3): 458-474.

Booth, S. \& Zeller, D. 2005. Mercury, food webs and marine mammals: Implications of diet and climate change for human health. Environmental Health Perspectives 113 (5): 521-526.

Campbell-Lendrum, D., Pruss-Ustun, A. \& Corvalan, C. 2003. How Much Disease Could Climate Change Cause?. In McMichael, A., Campbell-Lendrum, D., Corvalan, C., Ebi, K., Githeko, A., Scheraga, J. \& Woodward, A. (ed.). Climate change and human health: Risks and responses, pp. 133-159. Geneva: World Health Organization.

Checkley, W., Epstein, L.D., Gilman, R.H., Figueroa, D., Cama, R.I., Patz, J.A. \& Black, R.E. 2000. Effects of El Niño and ambient temperature on hospital admissions for diarrhoeal diseases in Peruvian children. The Lancet 355: 442-450.

Debebe, H. 1995. Food security: A brief review of concepts and indicators. In Multa, D., Wolday, A., Simeon, E. \& Tesfaye, Z. (ed.). Food security, nutrition and poverty alleviation in Ethiopia problems and prospects, pp.1-18. Addis Ababa: Agricultural Economics society of Ethiopia.

FAO. 2008. Climate Change and Food Security: A Framework Document. FAO interdepartmental working group on climate change. Rome: Food and Agriculture Organization of the United Nations.

Hoddinott, J. 1999. Choosing outcome indicators of household food security. Washington DC: IFPRI.

IPCC. 2007. Climate change 2007- Impacts, adaptation and vulnerability. Cambridge. UK. Cambridge University Press.

Kovats, R.S., Edwards, S., Hajat, S., Armstrong, B., Ebi, K.L. \& Menne, B. 2004. The effect of temperature on food poisoning: Time series analysis in 10 European countries. Epidemiology and Infection 132 (3): 443-453.

Kuhnlein, H.V. 2003. Micronutrient nutrition and traditional food systems of indigenous peoples. Food, Nutrition and Agriculture 32: 33-39. 
Lovendal, C.R. \& Knowles, M. 2006. Tomorrow's hunger: A framework for analysing vulnerability to food security, UNU- WIDER. Research Paper No, 2006/119.

Makinen, M., Waters, H., Rauch, M., Almagambetova, N., Bitran, R., Gilson, L., McIntyre, D., Pannarunothai, S., Prieto, A.L., Ubilla, G. \& Ram, S. 2000. Inequalities in healthcare use and expenditures: Empirical data from eight developing countries and countries in transition. Bulletin of the World Health Organization 78(1): 55-65.

McMichael, A., Campbell-Lendrum, D., Kovats, S., Edwards, S., Wilkinson, P., Wilson, T., Nicholls, R., Hales, S., Tanser, F., Le Sueur, D., Schlesinger, S. \& Andronova, N. 2004. Global climate change. In Ezzati, M., Lopez, A., Rodgers, A. \& Murray, C. (ed.). Comparative quantification of health risks: Global and regional burden of disease due to selected major risk factors, pp. 1543-1649. Geneva: World Health Organization.

Negatu, W. 2006. Determinants of small farm household food security: evidence from south Wollo, Ethiopia. Ethiopian Journal of Development Research 28(1): 1-29.

Shariff, Z.M. \& Khor, G.L. 2008. Household food insecurity and coping strategies in a poor rural community in Malaysia. Nutrition Research and Practice 2(1): 26-34.

Yohe, G.W., Lasco, R.D., Ahmad, Q.K., Arnell, N.W., Cohen, S.J., Hope, C., Janetos, A.C. \& Perez, R.T. 2007. Perspectives on climate change and sustainability. In Parry, M.L., Canziani, F., Palutikof, J.P., van der Linden, P.J. \& Hanson, C.E. (ed.). Climate change 2007: Impacts, adaptation and vulnerability, contribution of working group ii to the fourth assessment report of the intergovernmental panel on climate change. Cambridge, pp. 811-841. UK: Cambridge University Press.

Zalilah, M.S. \& Ang, M. 2001. Assessment of food insecurity among low income households in Kuala Lumpur using the Radimer/ Cornell food insecurity instrument - A validation study. Malaysian Journal of Nutrition 7: 15-32.

Zalilah, M.S. 1998. Growth status determinants of school age children from primarily lowincome households in the urban area of Kuala Lumpur, Malaysia: A focus on intrahousehold factors. PH.D Dissertation, Michigan State University of USA.

Zimmerman, M., DePaola, A., Bowers, J.C., Krantz, J.A., Nordstrom, J.L., Johnson, C.N. \& Grimes, D.J. 2007. Variability of total and pathogenic Vibrio Parahaemolyticus densities in Northern Gulf of Mexico water and oysters. Applied and Environmental Microbiology 73 (23): 7589-7596. 